\title{
Geopolitics and geoeconomics of the eurasian space in modern realities: scenarios of the strategic choice of civilizational systems
}

\author{
Roman G. Vlasov ${ }^{1}$
}

UDC 327:911.3(4/5)

339.9:911.3(4/5)

${ }^{1}$ Siberian School of Corporate Management, vlasov.roman.russia@gmailcom

\begin{abstract}
The article deals with the issues of the system organization of the economy and management in the Eurasian space. The methodological principles of the modern understanding of the problems of geo-economics of the world Eurasian economic and civilizational development are analyzed. Tools and technologies of geo-economic analysis of modeling and forecasting are considered: geo-economic civilizational space, geo-economic weapons, geo-economic wars, geo-economic atlas. From the socio-cultural point of view, the phenomenon of nonsystemic development of the Western Balkan states (excluding Croatia and Slovenia) is considered. Geo-economic wars at the end of the 20th century and their consequences within and along the perimeter of the Eurasian space have created "countries-systems", the development of which makes it possible to speak of the phenomenon of the use of geoeconomic weapons, the striking elements of which contribute to the formation of a philosophy of self-reliance, diversification of the economic model of the state, and the creation of a positive image. Countries - systems to form real instruments of investment attractiveness of the state, the formation of extremely effective development institutions. Determination of the main strategic goal - advanced economic development is an important tool, the derivatives of which are the patriotism of national business and representatives of state and municipal authorities in solving the problems of state development. Concerning the countries of the Balkan region, the term "non-systematicity" can be used to designate a phenomenon in which a given territory, on the one hand, is an element of a single European system and is perceived as an integral whole, but also in many ways break the connection with it. The future of the Eurasian economic space, the effectiveness of the nationallyoriented model of development of states and peoples united by the capacious name "Modern Eurasia" depend on the results of the predicted geo-economic war.
\end{abstract}

Key words: geo-economics, Eurasian space, socio-cultural code, development, economic systems, geo-economic weapons, countries-systems.

\section{Introduction}

Managing the development of countries and regions of the modern Eurasian space is a rather complex and multifaceted problem, on a qualitative solution of which many components depend economical, political, socio-cultural. The term "modern realities" implies an analysis of the theory 
and practice of managing complex regional economic systems in the post-like period. The world will be different, as we do not know. Regional economic systems must adapt to the elements of changing key processes in their essence. Successful solution of development problems, which means effective functioning, requires an understanding of the genesis, essence, and terms on the basis of which complex national and multinational models, projects, scenarios, and forecasts are developed. The problem of analysis and forecasting of development in solving economic and managerial problems and ensuring strategic goals in solving problems of an increased degree of complexity is possible in the development of special methodological foundations based on the geo-economic paradigm and interdisciplinary scientific idea, which is in alliance with the methods of strategic analysis [1]. As a scientific hypothesis, let us get ahead of the contours and content of the modern vision of the geo-economic atlas of the Eurasian space. If we analyze in more detail the theory and practice of governance in the Eurasian space from Lisbon to Vladivostok and another thesis related to the principled position that Russia is not located between the West and the East, but the West and the East are located to the left and right of Russia, which means that that the era of selfdestruction of Russia, after the global geopolitical catastrophe associated with the collapse of the USSR, has ended finally and irrevocably [2]. Eurasianism is defined as one of the world centers of geopolitics and geo-economics, in the space of which the socio-cultural, historical, economic traditions of Russia as a Great World Power are being restored. To define the territory in the geoeconomic atlas of a modern sense, the definition of the boundaries of the Eurasian space is of fundamental importance. The geography and boundaries of the modern Eurasian space have the following contour: the Russian Federation, Kazakhstan, Belarus, Armenia, Tajikistan, and Kyrgyzstan - current members of the Eurasian Economic Union, the former republics of the Soviet Union, the Western Balkan states (except Croatia and Slovenia), Turkey, Bulgaria, Romania, Greece, Cyprus. The principles for the formation of a modern vision of the Eurasian economic space can be:

- general geo-economic historical code - the states of the former Soviet Union;

- general geo-economic axiological code - the states of the former Soviet Union and Yugoslavia;

- a common ethno-confessional geo-economic code - Russia, Serbia, Belarus, Ukraine, Macedonia, Montenegro, Greece, Cyprus, Bosnia and Herzegovina.

- general geo-economic code associated with the immanent characteristics of the countries systems: Russia, Turkey.

\section{Scenarios of the strategic choice of civilization systems}

The strategic goal of economic models of the Eurasian space is to create on the geo-economic map a competitive one, which allows one to speak of itself as a real pole of economic power, a regional economic system. We believe that the reason for the formation of new poles of economic power is the collapse of the unipolar world, the geo-economics of which has been firmly held in recent years by the United States and its faithful satellite, the European Union. In our opinion, soon, in the Eurasian economic space, the geopolitical and geo-economic confrontation of the system countries will continue for the states that have undefined their civilizational choice. This list includes most of the states of the former Soviet Union and Yugoslavia. The goal of the United States in the unfolding new world geo-economic war is clearly to fight against the formation of a new global player - the Eurasian Economic Union, respectively, weakening the existing global players - the European Union and China. Entering the economic zones of China's interests associated with the Silk Road projects, with the tasks of consolidating the positions of the Euro-Atlantic civilization model through the technology of hybrid wars, creating a pole of instability, fomenting medieval religious wars, including between Western and Eastern Christianity, between Catholicism and Islam, between Orthodoxy and Islam in the civilizational and economic dimension - is a trend in the modern world order. Although the formation of a cooperation zone from Lisbon to Vladivostok is repeatedly spoken based on free trade and mutually beneficial cooperation, the integration processes that include Europe and China, 
as well as the Middle and the Middle East, are powerful stabilizing factors contributing to overcoming the global crisis and creating new development opportunities.

The realities of the Eurasian space dictate a new configuration of interests of global and local players in the economic atlas. This is due to the continuous geo-economic wars waged on the borders and within the Eurasian space. At the moment, the Eurasian economic space is divided into four poles of economic power according to the civilizational principle:

- Euro-Atlantic macro-region, which unites countries with the Western Christian civilization system; - the Eurasian macro-region we understand as a real heartland of the Eurasian space, uniting countries and peoples on a poly-confessional basis: Orthodoxy, Islam, Buddhism.

- Confucian macro-region uniting China and the countries of Southeast Asia;

- neo-Ottoman macro-region represented by Turkey and the countries of Europe and Asia, having common confessional interests, common history, shared common civilizational values.

The rest of the states of the Eurasian space are wandering reproductive nuclei or are in a specific, rather delicate situation in an alien civilizational field. So Bulgaria, Romania, Greece, and Cyprus are for some reason the most problematic and poorest relatives of the Euro-Atlantic civilizational model of functioning and development.

In the civilizational space of the modern Western Balkans, dramatic events are taking place associated with geopolitical and geo-economic doctrines that have all the attributes of geo-economic wars:

- the doctrine of "Great Albania";

- the doctrine of "Old Serbia";

- the doctrine of neo-Ottomanism;

- the doctrine of radical Islamism;

- the doctrine of pan-Europeanism;

- the doctrine of Eurasianism and the Russian world.

The states that are part of the Eurasian economic space have certain potential opportunities for economic growth and their own exclusive inherent competitive advantages based on historically formed national interests and values. Following the well-known formula "development is change plus growth" with which it is difficult to disagree, for a sustainable forward movement of regional economic systems, one should make maximum use of systemic forecasting based on the methodology of strategic analysis, as well as views on modern geo-economics. We believe that the origins of the current crisis state of the world economy and politics should be sought in the socio-cultural codes of civilizational development.

The United States and Western Europe, as the core of the Euro-Atlantic civilization, had a decisive influence on the movement of the world reproductive nuclei that form the world income of the end of the 21st century. The Soviet Union and the integrated associations of Eastern Europe - the Warsaw Pact Organization (OVD) and the Council for Mutual Economic Assistance (CMEA), the Socialist Federal Republic of Yugoslavia (SFRY), as a state and leader of the Non-Aligned Movement for objective and subjective reasons, ceased to exist. The processes of the late 80 s and early 90 s of the last century were the largest geopolitical catastrophe. The entire Eurasian space, except China and Turkey, found itself in a historical loss, at a certain time stage. The civilizational defeat perpetrated by the poles of economic power at the end of the 20th century by the Euro-Atlantic economic model completely changed the geo-economic map of the world. As a result, the Soviet Union ceased to exist, Yugoslavia dispersed to its national apartments, Czechoslovakia was divided into the Czech Republic and Slovakia, real hotbeds of instability were created in the Middle East, Central and Western Asia, the era of color revolutions began, solving the problem of strengthening the Euro-Atlantic economic model by forming a belt of countries -satellites who recognize the supremacy of Euro-Atlanticism in all spheres of public life.

German thinker Karl Clausewitz defined war as the continuation of politics by other violent means [3]. Indeed, in modern and recent times, the world civilization, the active players of which, representing the nucleus of economic power, solved the issues of redistribution of the geo-economic map exclusively by military means. The First and Second World Wars, their results became a vivid 
confirmation of the views of the German scientist. The recorded outcome of the Second World War was the so-called Cold War, which, from the point of view of strategic geo-economic analysis, on the one hand, fixed the civilizational economic field between the two poles of economic power - the EuroAtlantic space and its satellites and the Eurasian space, as well as wandering reproductive nuclei between the poles of economic power - countries of the "third world". On the other hand, a global economic war for world income has unfolded between the poles of economic power and the countries of the Third World. Since the 70s of the twentieth century, the poles of economic power to achieve their strategic goals began to use special geo-economic tools to solve their problems. Such instruments are geo-economic weapons, the use of which constituted the technologies of unleashing hybrid wars, which are inherently nothing more than geo-economic wars.

The winner of the geo-economic competition of two economic and civilizational systems - the United States and its Euro-Atlantic satellites created, according to the definition of the German scientist K. Jaspers, the phenomenon of "axial time" their strategic interests are at the mercy of the winner in the status of a satellite [4]. Modern instruments of geo-economic wars implemented through real technologies for the use of geo-economic weapons are economic sanctions, instruments of hybrid wars, the economic embargo imposed by countries-systems with the consent and without consent of the United Nations, geopolitical isolation formed through the technology of forming "double standards" according to the geo-economic model "rogue states", "color revolutions" to replace the political elite, erosion of elements of the socio-cultural code in multinational states, revision of the results and results of key events in the history of countries and peoples, the formation of a syndrome of historical guilt for the results of the historical process, the introduction of values alien to the civilizational state of a specific the country and its people, technologies of forced transformation of the civilizational foundations of states by resettling in them the population of a different civilizational type. The practical use of geo-economic weapons, the unleashing of hybrid geo-economic wars, especially from the countries of the Euro-Atlantic orientation systems and their satellites at the end of the twentieth century, led to serious, global changes in the geo-economic atlas of the world. It should be noted that in every war, especially in a geo-economic one, there are almost always winners and losers, albeit on a rather limited historical and time interval. From the point of view of theory, everything is obvious.

However, practice, tools of strategic analysis, and geo-economic forecasting allow us to trace not only the life cycle of a victorious march but also to conduct a practical analysis of the behavior of the defeated, his ability to solve national-state problems of development, recovery growth, achieve the effect of advanced development, overcoming the catch-up syndrome of the national economic model in the face of uncertainty associated with the consequences of geo-economic wars. Thus, the victory in the Cold War by the United States and the Euro-Atlantic countries - systems over the Soviet Union, named by the President of the Russian Federation - V.V. Putin, the largest geopolitical and national catastrophe, confirms the idea of the effectiveness of geo-economic weapons for solving strategic problems. But here we should also recognize the fact that the last leader of the Soviet Union, headed by M.S. Gorbachev, objectively and subjectively, exposed the country to a guaranteed defeat in a civilizational geo-economic war with the Euro-Atlantic civilizational system.

With the help of geo-economic weapons, the Socialist Federal Republic of Yugoslavia was also defeated, against which the technology of exacerbating confessional socio-cultural historical contradictions, the policy of "double standards" the priority of economic decisions over political expediency, and other tools of geo-economic weapons were used [5]. The opposite examples are also arousing interest. It is during the late 90 s of the XX century that we observe the creation of highly efficient and effective geo-economic models with pronounced national characteristics, which make it possible to speak of the emergence of new countries - systems whose economies are capable of developing and functioning steadily in any, even the most unfavorable circumstances. We are talking about the Russian Federation of the 21st century, China, Iran, Turkey, South Korea, Brazil, the "economic tigers" of Southeast Asia, India, Kazakhstan, Belarus. It should be borne in mind that the result of geo-economic wars against and along the perimeter of the Eurasian civilizational space is the formation of poles of instability on its southern borders, as a modern variation of civilizational confrontation. 
The problem of a global scale is the "boomerang effect" when it affects the actions of the countriessystems of the Euro-Atlantic orientation to form geo-economic chaos, when geo-economic weapons were deployed on the contrary, against the countries that initiated global and regional systemic crises. The victim was the European Union that was unprepared for crises, against which technologies of "controlled chaos" are used to massively resettle millions of refugees of Islamic civilizational culture to the territory of successful European countries with all the ensuing consequences for all types of European Union security, which, together with controversial issues, connected with the policy of further enlargement of the European Union, geo-economic war, one of the leaders of the Eurasian economic space - the Russian Federation makes the prospects of the European Union vulnerable both in the short and long term.

Geo-economic wars at the end of the 20th century and their consequences within and along the perimeter of the Eurasian space have created countries - systems, the development of which makes it possible to speak of the phenomenon of the use of geo-economic weapons, the striking elements of which contribute to the formation of a philosophy of self-reliance, diversification of the economic model of the state, and the creation of a positive image. Countries - systems to form real instruments of investment attractiveness of the state, the formation of extremely effective development institutions. Determination of the main strategic goal - advanced economic development is an important tool, the derivatives of which are the patriotism of national business and representatives of state and municipal authorities in solving the problems of state development. As a result, new countries-systems such as China, Iran, and Turkey appeared on the geo-economic map.

These countries-systems are real and potential leaders who form reproductive nuclei under their patronage and participate in the struggle for the distribution of world income. It should be noted that China, Iran, and, in many respects, Turkey has virtually no constitutional allies in the face of friendly states, and there are only strategic partners that contribute to solving the problems of global positioning in the world market, within the framework of values formed exclusively for each of the system countries. Taking into account a single socio-cultural code, a long period of common history, the preservation of the traditional single economic space, the Eurasian Economic Union was created as part of Russia, Belarus, Armenia, Kyrgyzstan, Kazakhstan. It should be noted that the Eurasian Economic Union is a powerful integration association of the Eurasian space, although it is still in its infancy. In terms of potential opportunities, the Eurasian Economic Union is able not only to become a bridge between China and the European Union but also in the long term to become a highly competitive integration association located in the center of the Eurasian space, in its heartland.

It is also interesting to note that the Eurasian Economic Union includes three of the four former countries of the Soviet republics, the combined economic power of which amounted to almost a quarter of the GDP of the USSR in the twentieth century - Russia, Belarus, and Kazakhstan, unfortunately, the exception is Ukraine, which is at the stage of objective and a subjective civilizational break, characteristic of countries with an uncompleted statehood, the disintegration of which is a matter of time. Thus, the results of the geo-economic wars at the end of the twentieth century caused the disintegration of the federal states of Europe, the elimination of the Council for Mutual Economic Assistance (CMEA), which unites the countries of Eastern Europe. A mosaic of small states with their characteristics of economic development and national interests has appeared on the geo-economic map of Europe [6]. If the states of Eastern and Central Europe and the Baltic countries changed their civilizational leader, moving to their historical opponent in the European Union and NATO, then the countries of Southern Europe took a more pragmatic position, expressed in balancing between the poles of economic power in the Eurasian space.

The basic geo-economic characteristics of the countries of Eastern, Central and Southern Europe are:

- a pronounced model of the catching-up economy in the system of priorities for the economic development of states;

- adaptation of the economic model to the standards of the European Union objectively reduces the possibilities of diversifying the economic development of states, including in the formation of development institutions and their communication with the poles of the economic power of the Eurasian space outside the zone of the European Union; 
- the catching-up economic model turns the countries of Eastern, Southern and Central Europe into the second and third echelon of the European Union, characterized by an increasing gap in the levels of socio-economic development with the first echelon - the core of the European Union [7].

Statistics is a stubborn thing, arguing with numbers is not a gratifying thing, however, issues of ensuring the competitiveness of the national economy require strategic analysis on a multi-level system. The following should also be understood - the syndrome "we are a country with catching up development", "we are a small country - help us, protect us - take us to your club" development, situational thinking, aimed at fixing the state.

The fixation of the state inevitably forms the effect of the "little man", which entails the formation of a separate stratification model within the elite, the characteristics of which are: catching-up thinking, a longer period of decision-making or not making them in principle, the syndrome of "driven" management as a counterbalance to the "leading" management, immunity to the design field, innovation and innovation.

\section{Conclusion}

Of course, the model of catching-up development, its systemic characteristics, the very philosophy of the national situation, at first glance, gives a negative background for the functioning of economic and political systems, determines the place and role of the state on the geo-economic map of Europe and the world. Yes, at first glance, everything is obvious and from the standpoint of real statistics, it is quite justified. Throughout history, as well as a modern development, the socio-cultural factor has a significant impact on the tendencies of the restoration of the economic and regional systems of the Balkan states in the post-view perspective. The presence of various actors, often acting in different socio-cultural positions: the European Union, the Russian Federation, Turkey, China, the Arab states, makes the systemic transformation of the Balkan countries an extremely vulnerable process, directly affecting the foundations of their geo-economic security. History shows that the course towards neutralizing external forces and concentrating the Balkans on any one concept has never succeeded. The idea of the European Union that all the Balkan countries are included socioculturally only in its geopolitical and geo-economic space has not been empirically confirmed. Unfortunately, the European Union does not correctly assess the effectiveness of its policy towards the Balkan states [8].

First of all, EU policy runs counter to the interests of all actors represented in the geo-economic atlas of the Balkan states. Such a policy of the EU is extremely uncomfortable for all the actors involved, this is because the prospect of including the Western Balkan states in the EU is receding. In practice, such a policy harms the European Union itself, instead of attracting investments, creating a favorable climate, using the socio-cultural characteristics of the region to strengthen interregional cooperation, the EU repels other actors. The EU is creating a permanent situation of uncertainty that harms investment and the business climate the most. It can be assumed that all the revealed negative trends in the development of the countries of the region will persist and will intensify. The situation can only change when the EU policy is brought into line with the real, and not fictitious, needs of the region, taking into account the specific situation of the Balkan states. The reasons for the lack of progress in organizing the economic model of the Balkan states lie in the conceptual misunderstanding by all international actors of the "non-systemic position" of these countries.

Concerning the countries of the Balkan region, the term "non-systematicity" can be used to designate a phenomenon in which a given territory, on the one hand, is an element of a single European system and is perceived as an integral whole, but also in many ways break the connection with it. The reason is that the Balkan states are simultaneously constituent parts of several systems and, accordingly, not a single one completely. The current idea of the EU that they are included - meaningfully, valuewise, economically, geopolitically - in its, and only its orbit, is not confirmed by practice. As a result, the development of the countries of the region stalls: the backlog cannot be overcome either by economic levers or by political procedures. Soon, a serious geo-economic confrontation between 
countries that are wandering reproductive nuclei will unfold in the Eurasian economic space. The future of the Eurasian economic space, the effectiveness of the nationally-oriented model of development of states and peoples united by the capacious name "Modern Eurasia" depend on the results of the predicted geo-economic war.

\section{References:}

1. Vlasov R. Russia and Serbia: geo-economics of communications, strategy of choice, civilizational break. Collection of materials of the 49th international scientific and practical conference "Actual problems of economic sciences", Novosibirsk, (2016) pp. 13-18

2. Glazyev S. Voluntary Union of Peoples. Izborsk club, (2014) - No. 2. pp.10-12

3. Karl von Clausewitz. About war. In 2 volumes, Moscow, (2002)

4. Karl Jaspers. The meaning and purpose of history, Moscow, (1991)

5. Maksakova M. Trends in the development of economic cooperation between Russia and the countries of the Western Balkans. - Monograph (2015) pp.102-105

6. Posazhennikova A. Institutes of macroeconomic development: methodology of project-oriented management, institutions of infrastructure for the development of the Eurasian space. Collection of materials of the 49th international scientific and practical conference "Actual issues of economic sciences" , Novosibirsk, (2016) pp. 23-30

7. https://www.worldbank.org/en/home

8. Terzic S. Old Serbia (XIX-XX centuries) The drama of a European civilization. Monograph, (2015) 